\title{
La fotografía y lo militar, su filosofía y su estética
}

\author{
Juan Pardo Despierto
}

EL TEDIO DE LOS IMPERIOS, CIENCIA Y ARTE COMO

REVOLUCIÓN

La fotografia nace en un espacio politico "estable", entendiendo por esto que las convulsiones emanadas de las revoluciones del verano de 1830 se encuentran muy amortiguadas, cuando no virtualmente olvidadas; tan sólo Bélgica, convertida en Estado independiente pero bajo las formas monárquicas, es el menguado resultado de la gran tormenta liberal que intentó desestabilizar la imperturbabilidad de los regímenes edificados a la manera que el Congreso de Viena sancionara en 1815. Sin embargo, las panorámicas artística y científica conocian grandes movimientos, fruto de una inquietud social que sólo en ellas podía verificarse. Es el momento brillante del romanticismo, una impronta clave del ser contemporáneo que se alargará durante décadas y que ha sobrevivido al ámbito preciso que la vio surgir. La fotografía se incluye con naturalidad -y expectación - en este mundo abierto de la mano de una comunidad avanzada en sus criterios y encabezada por Dominique François Arago, hombre que encarnaba a la perfección la simbiosis entre cientifismo y 
aventura ${ }^{`}$. Su intuición fue seguida a la letra por el gobierno de Luis Felipe, que no podía rechazar todo lo que de nouveauté - evidentemente no dogmática - apareciera.

Empezará entonces una larga connivencia entre Estado y fotografía, proceso que la revelación daguerriana adoptara con gran soltura, pero que terminará en involución, en otras técnicas, con otros nombres, pero sin duda siendo entonces sincera y respetuosa con su idea original: descubrir una nueva verdad, una nueva estética de la vida que terminaría por transformar los conceptos artisticos, sociales y políticos del hombre.

Ese estremecimiento, por la propia fotografía imprevisto, vendrá determinado por su aproximación a la noticia militar, al hecho bélico en sí, que primero se trató con heroica amabilidad y finalmente desbordó ese marco de complicidad para convertirse en el fiero sujeto que siempre fue. La fotografía tardó décadas en reconocer la trascendencia del descubrimiento. $Y$ el espacio político y social sufrió idénticos retrasos de conocimiento.

\section{REALISMO CIENTIFICO, ROMANTICISMO POLITICO}

Existe la tendencia a definir la fotografía en sus orígenes como un hecho exclusivamente romántico, cuando ésta es una impregnación posterior y no una primera consecuencia.

En un mundo artístico donde la batalla se libraba entre la exaltación -ya derrotada - por la antiguedad pagana, y su gran opositor triunfante, el medioevo, la fotografía no encuentra lógico acomodo intelectual. Ella

Dominique-François Arago (1786-1853). Formado en l'Ecole Polytecnique, junto con Biot inició en 1806 la medición del arco de meridiano de Paris, desde Dunkerque a BarceIona, lo que le llevaria a trabajos concretos sobre el espacio balear (Formentera). La guerra de la Independencia le sorprendió alli, por lo que se le consideró como espía; encarcelado en Mallorca, logró escapar y pasó a Argel, pero en su viaje de retorno a Francia fue capturado de nuevo y conducido preso a Rosas y luego a Palamós, recobrando su libertard en 1809. Miembro de la Academia de Ciencias de la que era secretario perpetuo desde 1830 - el mismo en el que es nombrado director del Observatorio-, se especializó en los campos de la optica, la mecánica celeste y la geografía física (descubrió la polarización magnética, lo que le valió la medalla Copley). En 1839, momento de su solemne discurso de apoyo a la fotografía, era ya un destacado político republicano (diputado desde 1831). Al advenimiento de Napoleón III se retiró de la vida pública, pero siguió siendo un punto nítido de referencia, en lo moral y en la ciencia, para todo el ámbito europeo. 


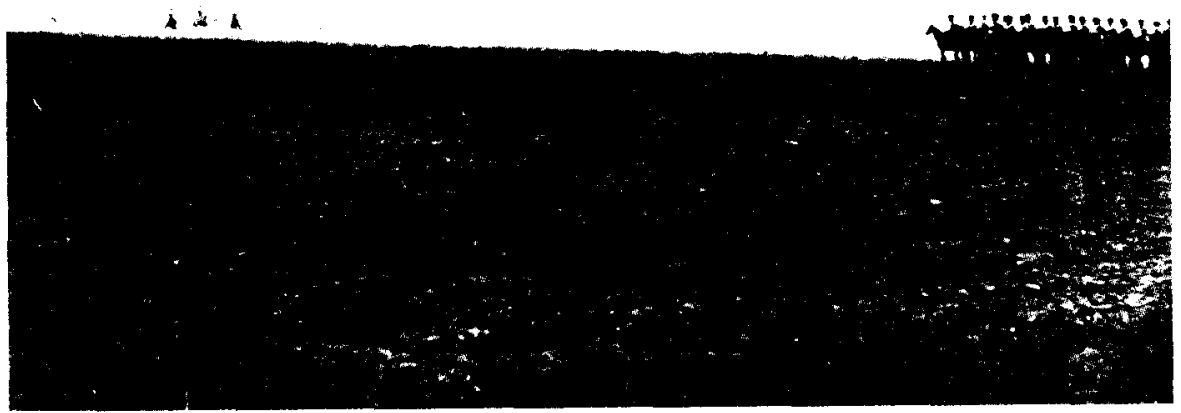

Foto 0. "Maniobras de la caballeria" (Campo de Châlons, 1857). Gustave Le Gray.

es, por encima de cualquiera otra definición circunstancial, fundamento científico y sintesis utilitaria, producto de un mundo posilustrado y a la vez reverante con la filosofía de Stuart Mill. Pero la fotografía portaba en si el soplo vivificador de la aventura, hecho innegable que se demostró con inmediatez en los terrenos estéticos donde el romanticismo se definia con contundencia: la excitación por los mundos perdidos, exóticos (el reencuentro con África y Oriente); la valoración de ancestrales ideales (patria, valor, libertad), todo ello unido a una glorificación de las pasiones del alma y de las urgencias del cuerpo: amor, destino, locura, posesión, sensualidad. La gran marea romántica se extendía asi desde el "Ivanhoe" (1819) de sir Walter Scott al "Hernani" (1830) de Victor Hugo; de "La balsa de la Medusa" (1819) de Théodore Géricault al luminoso torbellino de "Lluvia, niebla y velocidad" (1844) de William Turner, y del teatro de Schiller al ballet de Karl Maria von Weber en "La sífide" (1832), sin olvidar el nacionalismo de Fichte y la nostalgia igualmente pasional de Fréderic Chopin en sus "Preludios" (1839) mallorquinos, que 


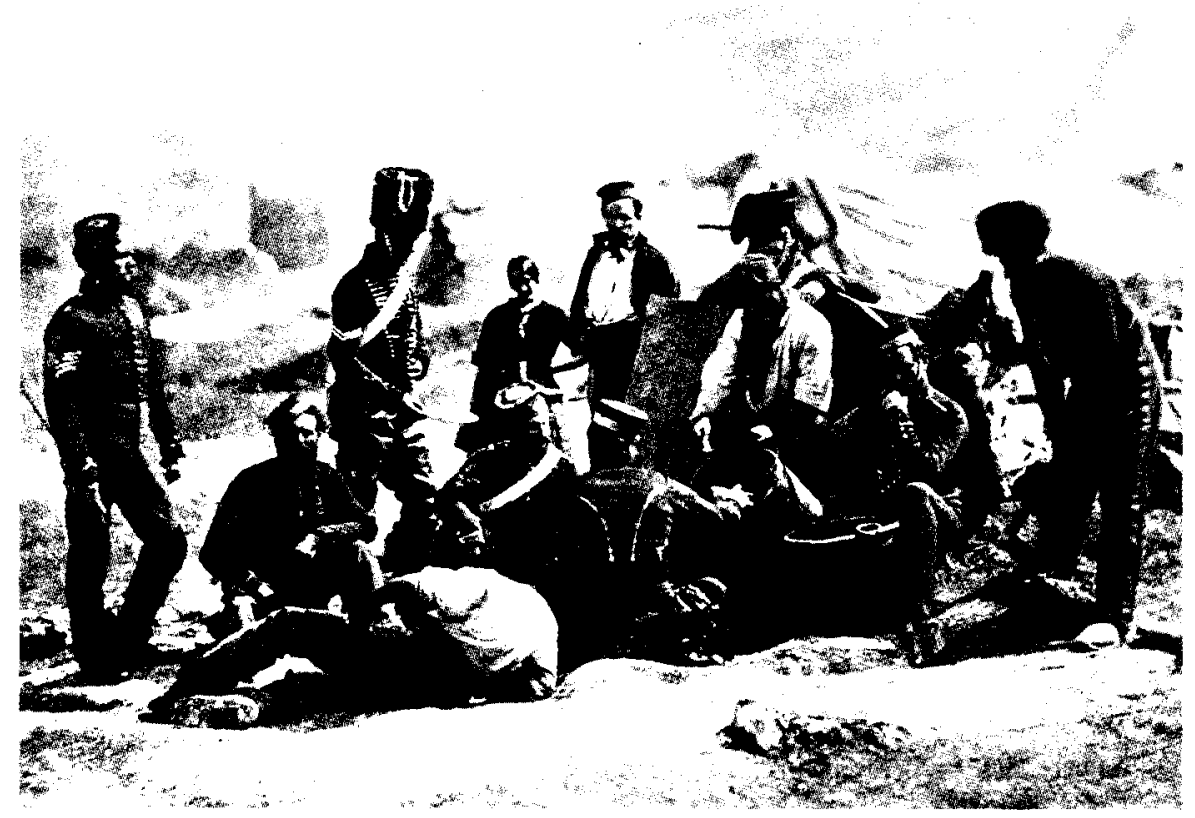

Foto 1. "La cocina del 8th de húsares". Roger Fenton.

ven la luz cuando Arago expone solemnemente la fotografía como objeto de culto científico ante un mundo discretamente atónito ${ }^{2}$.

La fotografía es, pues, un medio de expresión directo de una clase científica absorbida por su trascendencia (Herschel, von Madler) que serán quienes den forma y conciencia al poder descubierto -en su epistemología y en su realismo cotidiano- ${ }^{3}$. La conjunción de grandes inves-

${ }^{2}$ El 19 de agosto de 1839 , en el Instituto de Francia, en sesión conjunta de la Academia de Ciencias de Paris y los miembros de la Academia de Bellas Artes.

${ }^{3}$ John F.W. Herschel (1792-1871). Reputado astrónomo igual que su padre, William. Seducido por la comunicación de Arago, entró en contacto con Henry Fox Talbot, autor del proceso de calotipo (por kalos, "bello"), un procedimiento basado en un papel trabajado con sus sendas soluciones de nitrato de plata y yoduro de potasio. Talbot y Herschel mantuvieron una estrecha relación, y el segundo, para superar amistosamente la definición talbotiana de "dibujo fotogénico" - por su memoria "Some Account of the Art of Photogenic Drawing", 1839, leida ante la Royal Society de Londres-, propuso el término "fotografía" (del griego phos, photós, que equivale a "luz" y gráphein, "grabar"). En cuanto a Johann Heinrich von Madler, prestigiado astrónomo germano, presentó la palabra "Photographie» en un artículo publicado en la Vossische Zeitung del 25 de febrero de 1839. 
tigadores -una constante en el hecho fotográfico- y el apoyo institucional de una política que, como la luisfelipista, sabia perfectamente qué hallazgos sociales alentar - la fotografía fue casi instantáneamente clasificada como objeto de "necesidad nacional», reforzó sus cimientos expresivos y facilitó una dinámica comunicativa que no parecía tener límites, tanto en su difusión como teologia sorpresiva de la existencia y de la reverencia social, como en su facilidad de aproximar ilusiones y estrategias, los grandes viajes: Joseph-Philibert Girault de Pangrey hacia el mundo árabe (1842-44); Jean-Baptiste Gros en Colombia y Grecia en la misma época; los ópticos Chevalier y Lerebours financiando y editando expediciones hacia Francia y España, o Maxime du Camp en Egipto (1849-52). Era la persecución en pos de los mundos extraños, siempre estimulantes en una coherencia política que cubriria el área euroatlántica como núcleo de un pensamiento expansivo, y que condujo a que la fotografía fuese el instrumento catalizador de una estética de dominio, al apartar panorámicas monumentales y silentes, espacios desvastados de toda presencia de Estado, donde la magnificencia de las poderosas culturas semienterradas hablaban por si solas de la importancia histórica y estratégica que allí aguardaba la llegada de nuevos dioses, de nuevos dueños. La fotografía fue asi el mensajero explícito y revelador para gigantescos poderes absortos ante sus noticias, y que se demostrarian implacables sobre ellas. Esta fotografía viajera, con ser connatural a una demanda del realismo científico euronorteamericano, derivó pronto en una tendencia indeleble hacia los objetivos por cumplir de un romanticismo político que pronto perdería todo sentimiento nostálgico y que terminaría aplicando rígidas formas de pensamiento y explotación coloniales.

Esta fotografía descubridora de horizontes arqueológicos fue bendecida por las instituciones, desde los clubes londinenses a los círculos de poder continentales. Enseñaba muchas cosas: las magnitudes fotográficas y culturales por investigar; la inmersión de estas densidades en un silencio intemporal del que debian ser rescatadas; la notoria ausencia de formas modernas de Estado y de Ejércitos afines que las salvaguardasen; todo ello en justa correspondencia con una universalidad de evidencias sociales que se demostraban oscurantistas, compartimentadas, ámbito extremo de lo fanático y regresivo. Este horizonte salvaje e intolerante -por su clima, su religión y su política-, y a la vez inerme y abandonado, favoreció ambiciones expansivas de carácter institucional y determinó ilusiones románticas en lo particular. Una nueva Odisea, más aún, una iluminada Cruzada se tornaba perceptible ante las convicciones intimas del ser europeo por medio de sus sentimientos filosófico-estratégicos. 


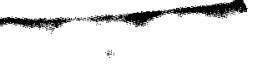

$\Delta$

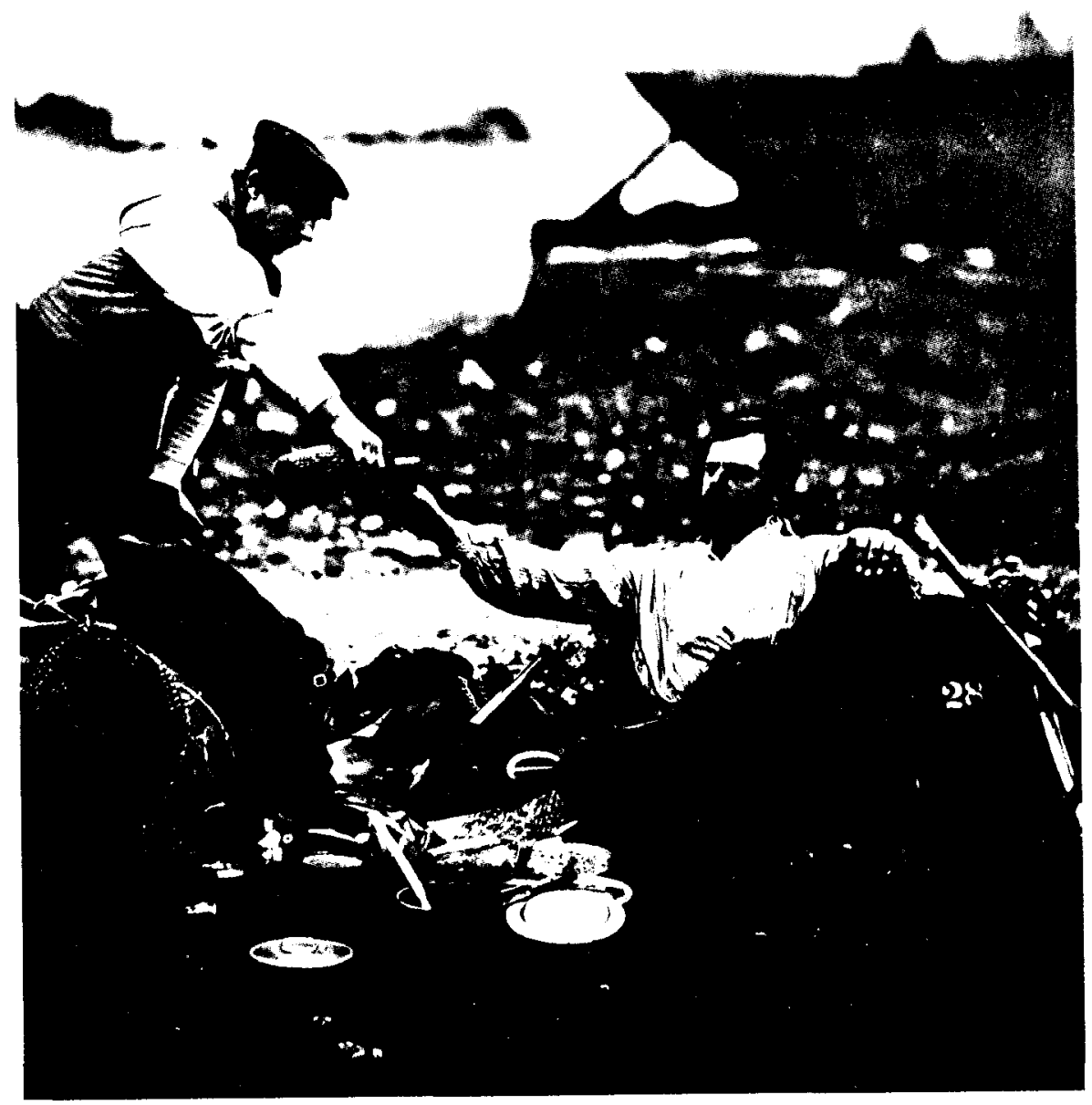

Foto 2. "Asi comienzo el dia". Roger Fenton. 
David Hume, en su Tratado sobre la Naturaleza humana (1739-40), habria ya mostrado una especial crudeza al definir las capacidades disminuidas, no ya estéticas sino familiares, del poblamiento negroide en los mundos africanos ${ }^{4}$. Incluso Inmmanuel Kant, con ser un foco de cordura sensitiva, de luminosa afirmación hacia la razón, había mostrado en $O b$ servaciones sobre el sentimiento de lo bello y lo sublime (1764), un etnocentrismo descarnado que, elevándose desde la frialdad jerárquica de Hume, terminaba por situar a los seres pertenecientes a los confines afroasiáticos, y particularmente al hombre negro, en el escalafón más bajo del posibilismo humano ${ }^{5}$. Estos prejuicios «ilustrados" tendrían su importancia fundamental posterior cuando la fotografía y lo militar confluyesen en un estremecido choque de influencias en las costas de China o en los recónditos parajes hindúes. Con ser la muerte una afirmación cruel a la que el romanticismo nunca había vuelto la cara -es más, por no desfallecer ante ella, ante su imagen, recibiría de su transcendencia simbolista uno de sus principios argumentales-, el impacto con la muerte no instituida, esto es, la muerte contundentemente demostrable en el hecho fotográfico, resultaba obviamente menor si esa atroz certidumbre se afirmaba en los cuerpos exánimes de seres ignotos, "distintos", inevitablemente inferiores. Sin embargo, en ese preciso instante la fotografia perdió todo su hálito romántico, toda su vinculación con el poder político y se hizo sujeto incómodo, como testigo, como fiscal. Y el realismo originario de su idea conmovió conciencias y estéticas, bien que en una propagación lentísima y que se quiso reconducir institucionalmente.

\section{ACADEMIA Y ESTADO MAYOR, COALICION ECLÉCTICA}

La fotografía nació, como toda criatura cientifico-artística de condición primeriza, con grandes voluntades descubridoras y un evidente carácter de servicio, bien hacia la sociedad y la ciencia, bien hacia los modos y maneras de quienes reconocía como sus superiores: las Bellas Artes.

Consecuente con estos principios de altruismo y conservadurismo, la fotografia se orientó hacia un compromiso: reforzarse en lo científico - la búsqueda de nuevos procedimientos que mejorasen su técnica fue una

\footnotetext{
4 "Las referencias sobre el pensamiento de Hume y Kant", en Bermejo BarRera, José Carlos, El final de la historia, Madrid, Akal, 1987, págs. 137 y 138.

5 Ibidem, págs. 151 y 152
} 


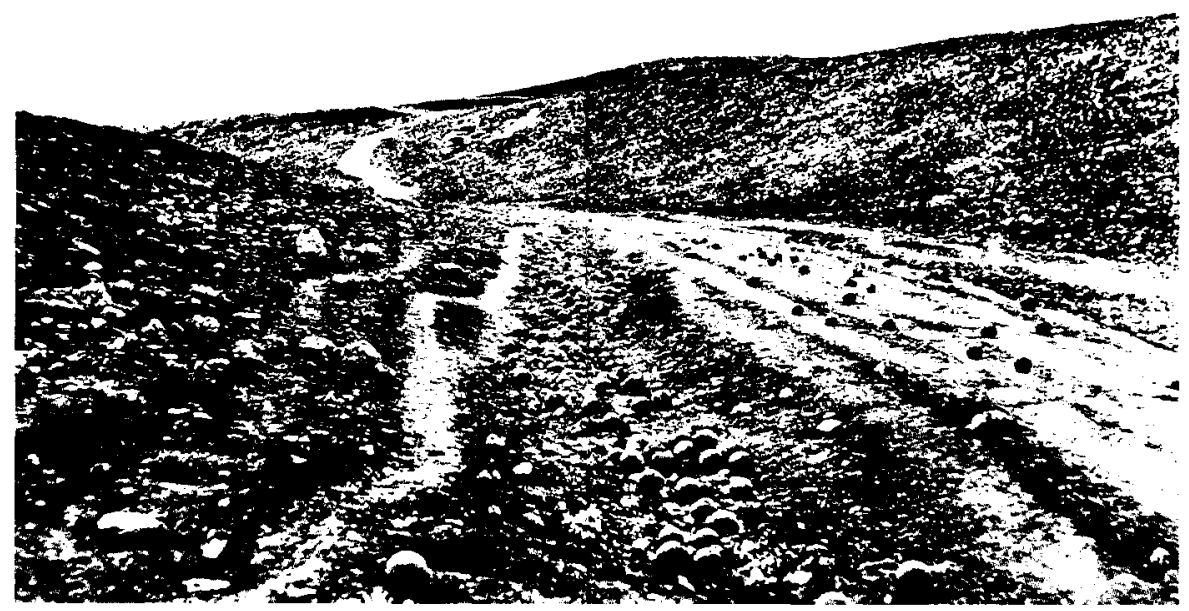

Foto 3. "El valle de la Sombra de la Muerte". Roger Fenton.

de sus constantes y hoy mismo sigue siéndolo- y cumplir ordenadamente su función social, es decir, satisfacer adecuadamente la demanda estamental (la fotografía como demostración del yo) y a la vez exponer su funcionalidad científica en el amplísimo marco de los usos decorativos, en la vida de salón (la fotografía como documento amable). De esta forma creyó ganar la solidez económica -cuestión que, efectivamente, supuso un sonado triunfo-, y recibir sincrónicamente el aplauso académico por sus indefiniciones estéticas: fidelidad sincera hacia quien considerada indiscutible ideal, la pintura. Habia críticos en su propio seno, claro está, pero los críticos ya es sabido que tienen pocas posibilidades de trascender el marco de su propia opinión. Esta admiración se percibía en su sentido lineal, monocorde, de la composición, y en un reflejo simultáneo en su cuidado por la iluminación que, a lo más que pudo alcanzar fue a una glorificación del efecto "Rembrandt", generador de indiscutibles obras maestras (Henry Peach Robinson), pero no factor determinante de nuevas tensiones, de afirmaciones de su propio principio.

La fotografía insistentemente sumisa a la pintura, numerosas críticas de raíz contra ella fueron despejadas por ello, pero la vacilación derivó en un continuismo de sus veneraciones superiores que acabó por llevar tanta lealtad, tanto mimetismo, al rincón más absurdo de la beatería artística. Entonces se consideró esto un acierto - la fotografía siguiendo los pasos de la moral pública-, y de ahi la sorpresa de su revolución estética posterior (Peter Henry Emerson con su manifiesto «Naturalistic Pho- 


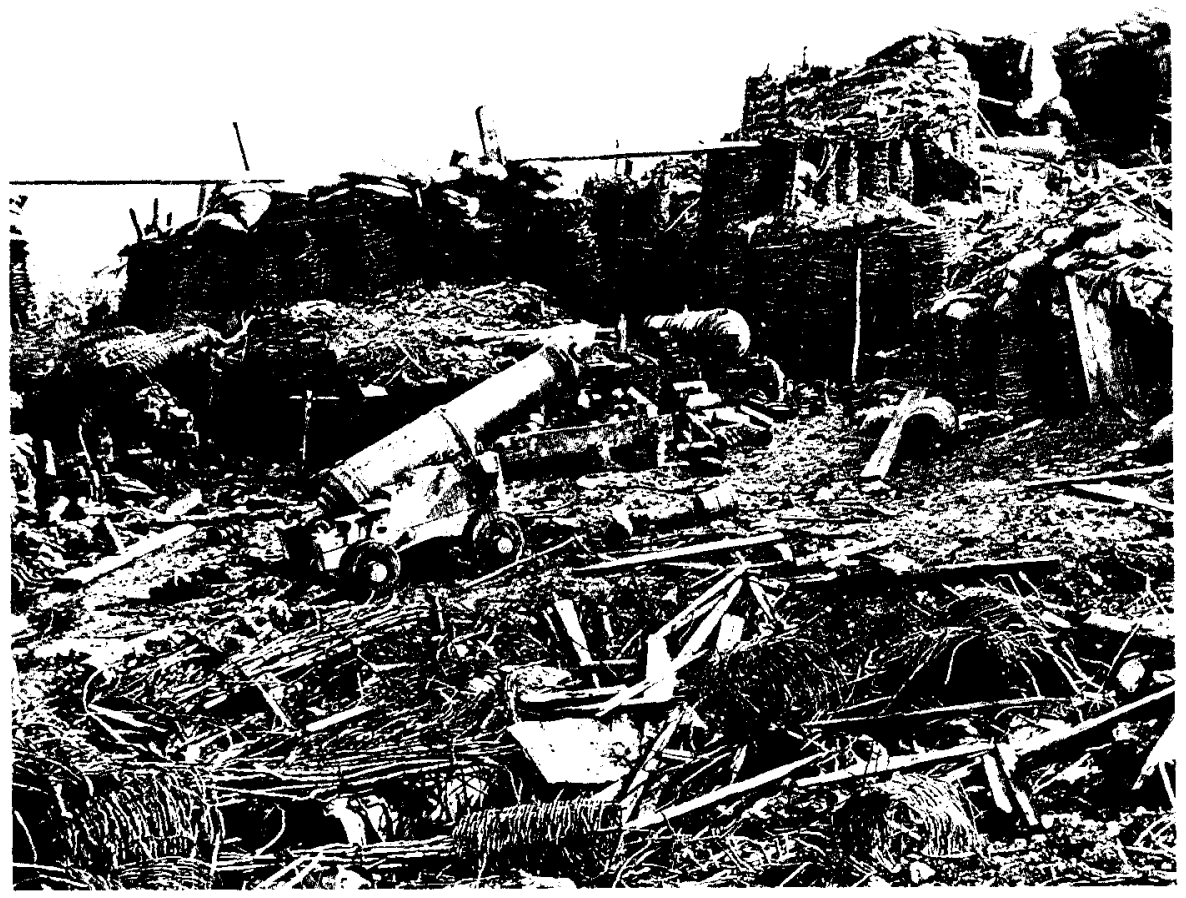

Foto 4. "Interior del Gran Redan" (Sebastopol). James Robertson.

tography", 1889), que vendría impuesta no sólo por la defensa de una realidad plástica natural, no artificiosa, sino por una superación intuitiva de la muerte estética de la fotografía oficialista. Impulsos creativos que ya habian eclosionado y que superaban con holgura el ámbito romántico, expresividades que llevaban al hombre hacia esencias plásticas hasta entonces desconocidas, las series fotográficas logradas por Julia Margaret Cameron entre 1864 y 1867 su más profunda y sensitiva representación ${ }^{6}$.

Naturalmente nada de esta coherencia interior era perceptible, la fotografia siguiendo a la letra las medidas de uso - y de venta- de la

${ }^{6}$ Julia Margaret Cameron (1815-1879). Sus retratos a un selecto círculo de amigos (la señora Herbert Duckworth, madre de Virg. Wolff) y de personalidades de las ciencias y las artes (Thomas Carlyle, W. Herschel o G. F. Watts), permanecen modélicos por su audacia compositiva, la expresividad de su iluminación y la capacidad para interpretaı el "alma" del personaje. 


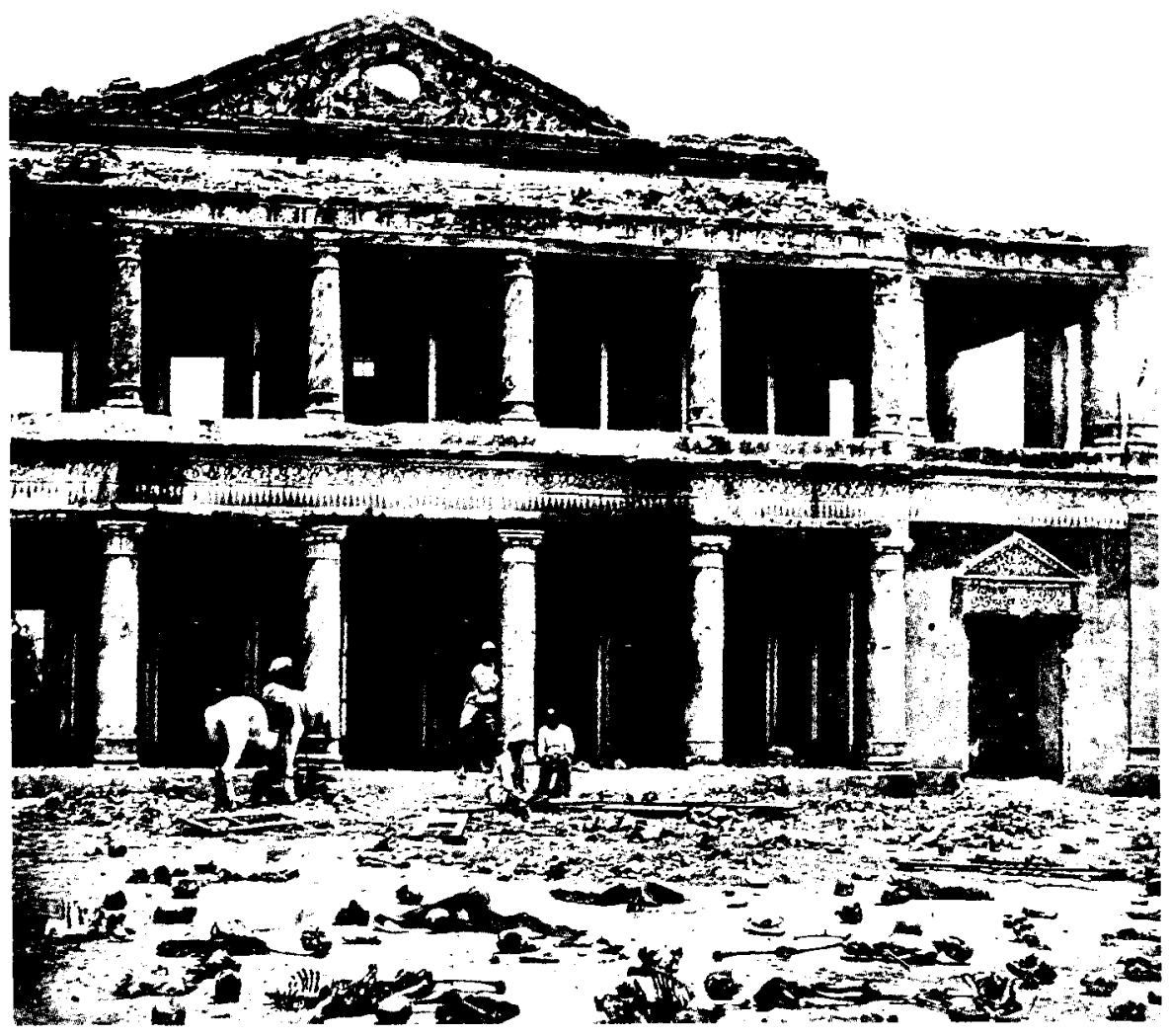

Foto 5. Sin titulo (esqueletos de los amotinados en Lucknow, 1858). Felix $A$ Beato.

sociedad de aquel mundo prerrevolucionario. El hecho fotográfico se convertía en una demostración pacífica de los nuevos tiempos, sus originales siempre encuadernados al concepto de una estabilidad social y política; lo armonioso, lo heroico y lo exótico traducidos, resumidos - en su definición del paisaje, del retrato o de la noticia- en un eclecticismo que nunca resultaba aniquilador de lo conocido, de lo «real». La fotografia fue asi refugio de lo inteligible, bien que ello la condujera al papel subordinado de intérprete de viejas secuencias, viejos dramas cansinamente repetidos en la historia y en los modos sociales. La fotografia, por comodidad financiera y por confusión ideológica, tuvo miedo de sí misma, y se convirtió en un simple centro reproductor de mandatos clasistas e institucionales. Resultó una equivoca seguridad estética que encajaría con 
notorio desconcierto su encuentro con la verdad a través del traumatismo bélico.

La fotografia pudo asi asistir, con imponente sentido de lo mayestático, a la gran convulsión de 1848. Un original a la albúmina, conservado en la Societé Française de la Photographie ?, muestra una apática perspectiva de la "Rue Royale", centro de brutales choques cuerpo a cuerpo y donde se sucedieron las descargas contra un mundo caduco y corrupto que fue allí desalojado de un terrible empellón populista e intelectual. Pero la panorámica, tomada a media altura, muestra una confusa acumulación de escombros; el tráfico restablecido y varios carruajes dando testimonio de "normalidad». El juicio palpitante y demoledor de 10 que significaba la palabra "barricada" quedaba de esta forma adormecido por esta cómoda representación de la violencia, que más parecía documento anónimo de obras de pavimentación y alumbrado que testimonio de feroces luchas sociopolíticas.

Superado el sobresalto europeo, la fotografía no se consideró aludida por el aviso - habia estado presente en la guerra mexicano-estadounidense (1846-48) y "nada» habia sucedido ${ }^{8}$-, con lo que la moral luisfelipista, barrida de las Tullerías, volvió como inquilino del nuevo dueño, un bonapartismo que se pretendía revolucionario y que quedó en luisnapoleonismo. A fin de cuentas, el mundo vivia entonces un reconocimiento de lo ecléctico, la unificación de ideas y tendencias infinitas que podia asumir todo lo que la mente - y la paciencia- del hombre pudiera ser capaz. La fotografia, inconscientemente, creyó también factible acomodar en su seno, en una misma arquitectura oficial, lo romántico y lo revolucionario, lo furioso y lo tiránico.

Víctor Cousin, el apóstol del movimiento ecléctico, decía en su "Cours de Philosophie» (1836): “Es necesaria la religión por la religión, la moral por la moral, el arte por el arte. El bien y lo justo no deben ser el camino de lo útil, ni de lo bello incluso". Estas interpretaciones no fueron entendidas en conciencia, derivando en un espiritualismo acomodaticio y circunstancial que produjo aberraciones singulares, desde el ur-

Hyppolite Bayard (1801-1887). Precursor, en su ciencia y en su estética, del hecho fotográfico, se limitó en el medio fotoperiodistico a reproducir una panorámica al uso de los sucesos que conmovieron el París luisfelipista. Rosemblun. Naomi, en su A world history of photography, New York, Abbeville Press, pág. 179, ofrece una deficiente reprodución de este original a la albúmina.

" "Las campañas en México", en R. N. Katcher, Philip, The Mexican-American War (1846-1848), London, Osprey, 1979, págs. 6-27. Los originales son todos al Jaguerrotipo y de autores anónimos, previsiblemente norteamericanos. 


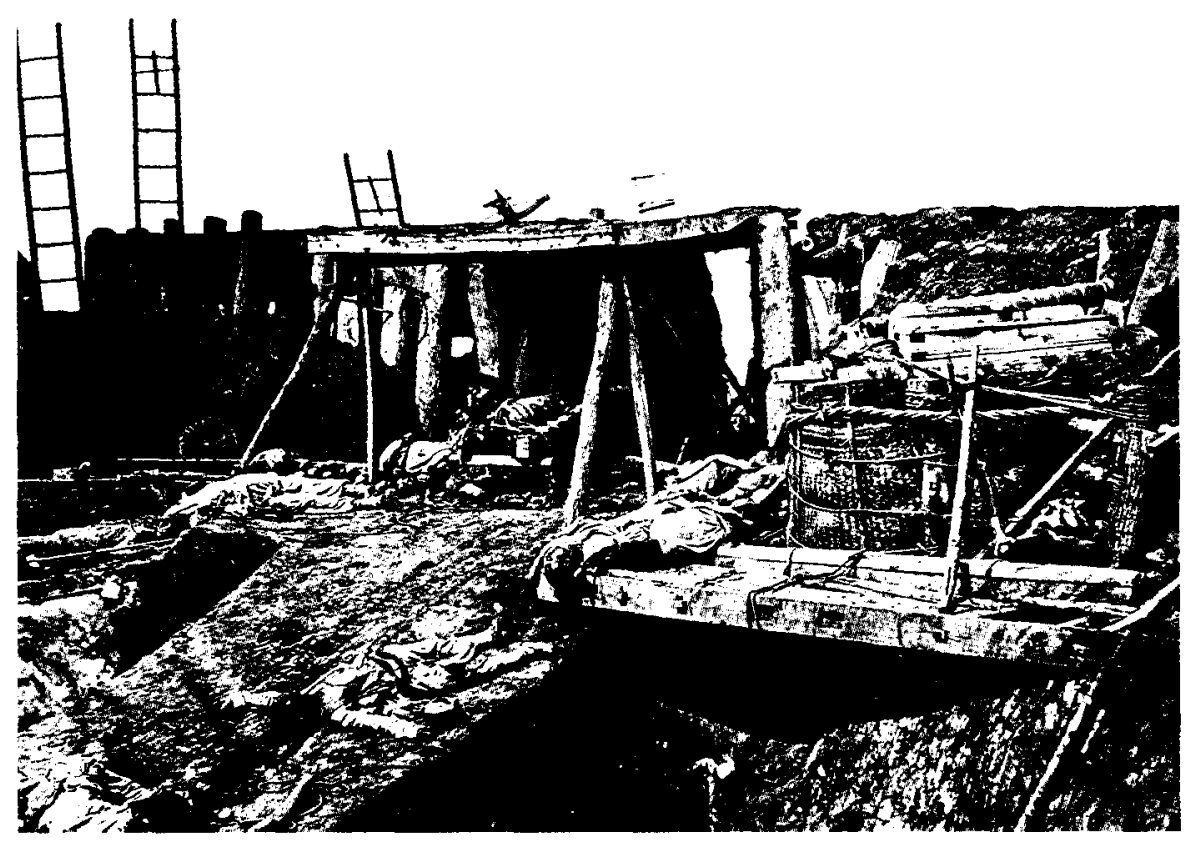

Foto 6. "El fuerte de Takú después del asalto" (Guerra del Opio, 1860). Félix A. Beato.

banismo a las normas de Estado. La fotografía, vestal humildísima entonces en el templo sublime de las grandes artes, tan sólo se limitó a escuchar y cumplir con su cometido doméstico. Su interpretación del mundo militar y político se atuvo a estos miramientos, realizando fatigosas series iconográficas y otras, que se presumian como encuadres renovadores, y que no superaban una linealidad de conceptos, de pensamiento, que la aproximaban a una plástica "renancentista» y giottesca. La paz, la gravedad del orden establecido, lo imbuia todo, incluido el ámbito de 10 noticiable y lo militar-revolucionario, lo periodístico y lo verdadero, sinónimo de tajante conspiración que debía ser diluida en el tedio de una interminable conferencia de rígido esteticismo.

Sin embargo, el mismo hecho de la presencia militar trascendía las estereotipadas interpretaciones del oficialismo fotográfico. Gustave Le Gray, un fotógrafo forjado, como tantos otros, en el espíritu de la pintura - discípulo de Paul Delaroche- y autor de una sencuencia excepcional sobre la conjunción de las formas terrestres y marítimas de carácter 
turneriano ${ }^{9}$, realizó en 1857 una de las más impresionantes tomas fotográficas de su mundo, sensación que era válida no ya para toda una época, sino para la historia militar.

En el campo de maniobras de Chalons un escuadrón de granaderos a caballo de la Guardia forma una masa sólida, impenetrable, atento a una voz de mando que se intuye inminente. La niebla envuelve, solemne y pérfidamente, la panorámica. En el extremo opuesto de la composición, unas figuras de jinetes representan al Estado Mayor, la inmediatez de la sentencia, la decisión que arrastrará hacia lo desconocido, en este momento engañosamente apacible, pero que se presiente terrible, pues la imagen captada por Le Gray nos transporta a la indefinición sutil entre la vida y la muerte; el escuadrón a punto de lanzarse como un resorte, en una carga masiva contra un blanco imaginario o un blanco real, la vida siempre en peligro en esta fusión disciplinaria de hombre y caballo, de individualismo y corporación ${ }^{10}$. Faltaba la confirmación de esa tensión.

\section{GUERRA Y ORDEN, UNA PINTURA EXTERIOR}

Nicolás Boileau, un preceptista molieriano e historiográfo de Luis XIV, pese a ello dotado de una rara sinceridad post-descartista, se explicaba así en sus Epitres: "Sólo es bello lo verdadero; lo verdadero sólo es amable" (que puede identificarse con el sentido de "poder ser amado"). Esta reflexión poetizada de la vida buscaba una aproximación ejemplar de la verdad, idealismo siempre esquivo, y más en lo romántico. Cuando la Inglaterra victoriana y la Francia napoleónica en segunda pasión se fueron ambas a la guerra, por primera vez unidas militarmente -políticamente, no- en los tiempos modernos, persegian una verdad parcial. Su enemigo: el Imperio ruso de Nicolás I, mundo autocrático y devorador de pueblos -la mítica Polonia, los principados danubianos, despotismo que excitaba un afán de libertades victorhuguetistas y byronianas-, en-

${ }^{9}$ Gustave Le Gray (1820-1862). Pintor transformado en fotógrafo, y seguidor en sus origenes pictóricos de la Escuela de Barbizon. Sus marinas, dotadas de una luminosidad y serenidad inimitables, le valieron el primer premio en la Exposition Universelle de 1855 y una fama que permanece.

${ }^{10}$ Le Gray fue un destacado representante de los gustos artísticos del Segundo Imperio, pero en sus originales, ya fuese en el paisaje o en este encuadre de índole militar que comentamos, definió con agudeza y elegancia una especial tensión, caracteristica de su estética fotográfica. 


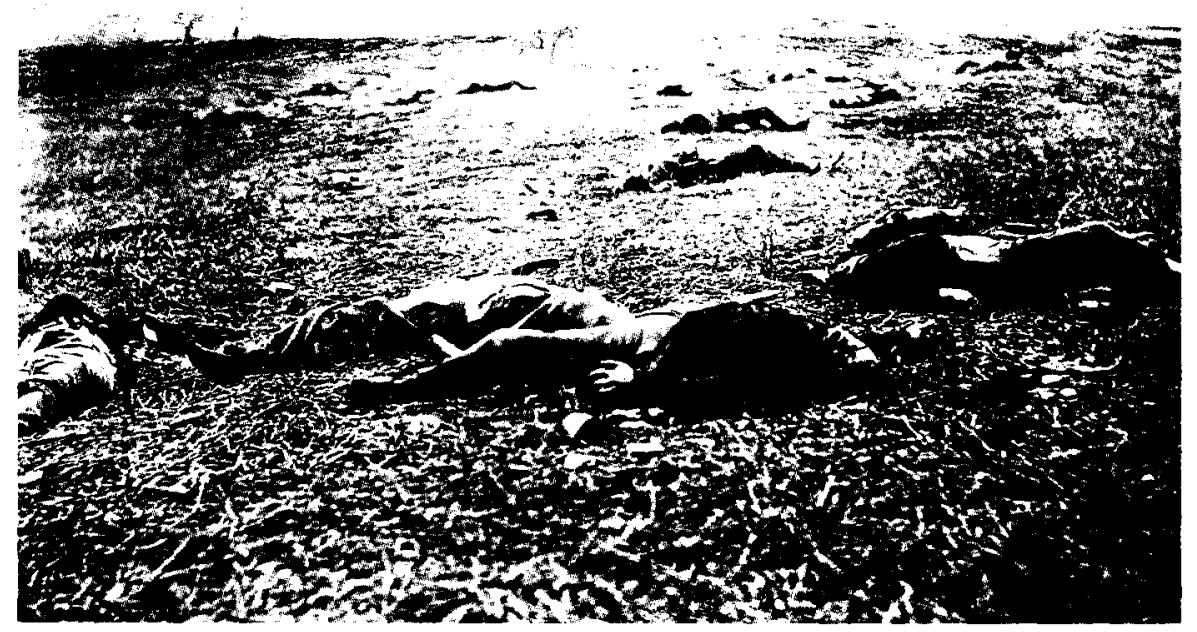

Foto 7. "La cosecha de la Muerte" (Gettysburg). Rimothy H. O'Sullivan-Alexander Gardner.

carnando a la perfección las definiciones de "salvaje y exótico» que no podian por menos de conmover las concepciones románticas eurooccidentales.

"Las fotografías suministran evidencia». Esta frase de Susan Sontang habla por si sola de una veracidad connatural a la idea fotográfica, luego transformada en mensajes opuestos (por un abstraccionismo evolutivo) o criminólogos (la fotografía manipulada no como tensión artística sino como función penitenciaria y fiscal, en la represión versallista contra la Commune, 1871). Esa verdad intrínseca al hecho fotográfico inquietaba mucho. "Fotografiar es conferir importancia" dijo también Sontang ${ }^{11}$ y esa trascendencia que ahora aceptamos como natural entonces se intuyó, en la mente fotográfica y en la psiquis del Estado, como un pecado mortal para ambos si caían en esa tentación expresionista.

La fotografía fue a la guerra de Crimea con mala conciencia. El espectáculo aterrador de un caos agobiante y mortífero en los servicios

"Sontang, Susan, Sobre la Fotografia, Barcelona, Edhasa, 1981, pág. 15 y pág. 38. 
sanitarios y de alimentación, unido a la ferocidad de un combate interminable ( 350.000 bajas entre ambos bandos), la hizo ser extremadamente precavida al testificar sobre esta ceremonia de la desidia y la impiedad que Europa aceptó como "lógica" ${ }^{12}$. A la epopeya asistieron selectos grupos de viajeros occidentales, militares unos - tres Comisiones españolas se sucedieron en el área, sin contar con la presencia anterior, en el tiempo y el espacio, de la encabezada por Prim en el escenario de la guerra danubiana entre rusos y turcos, en 1853-54, y de etiqueta otros. Uno de estos curiosos, en nada preocupado por el dandismo de haber asistido a la hecatombe de moda en Europa, fue Roger Fenton, un prestigiado fotógrafo británico, especializado en arquitectura y exquisitos bodegones, que realizaría en la península de Crimea lo que ha venido considerándose como el pistoletazo de salida de la fotografía militar en campaña; el arranque brillante de un reporterismo bélico que luego tendría magistrales sucesores.

Fenton y su fiel ayudante, Marcus Sparling, un fotógrafo emprendedor - constructor de máquinas de estudio-, llegaron a Balaklava en la primavera de 1855. La siniestra ensenada, abrigo del grueso de la flota expedicionaria, parecía el lugar menos idóneo para componer una secuencia pictoricista y heroica al gusto de la época: tan sólo una penosa acumulación de aridez y un maremágnun delirante de hombres, pertrechos y enfermos en resignado desfile cotidiano. Sin embargo, la pareja Fenton-Sparling, identificada muy pronto por su peculiar carromato-laboratorio llamativamente pintado en rojo y blanco, sabria realizar, en sus originales al colodión húmedo - de dificilisimo manejo con altas temperaturas-- una de las más hermosas y sensitivas páginas de la historia de la fotografia.

Fenton buscó sus protagonistas básicamente en los cuadros de oficiales y altos jefes, pero tampoco desdeñó el encuentro con la tropa, y ahí está su famosísima "Cocina del 8th de húsares" para confirmarlo, una muestra del naturalismo que Fenton llevaba dentro. Nuestro autor permaneció, siempre y conscientemente, dentro del marco jerárquico y

12 Cfr. Despierto Pando, Juan, “Españoles en Oriente: campañas del Danubio y Crimea". Revista de Historia Militar, Servicio Histórico Militar, núm. 62, Madrid, 1987, págs. 93-146. Friedrich Engels estudió la guerra en una recopilación de artículos sobre estrategia militar entre 1848 y 1874. Los que hacen referencia a la guerra de Crimea son los publicados el 27 de noviembre de 1854 y el 25 de enero de 1856 en el New York Daily Tribune y los pertenecientes al 8-9 de enero de 1855 y 20 de marzo del mismo año, publicados en el Neue Order Zeitung. La edición en castellano de estos análisis en ENGLES, F., Temas militares, Madrid, Akal, 1975, págs. 71-103. 


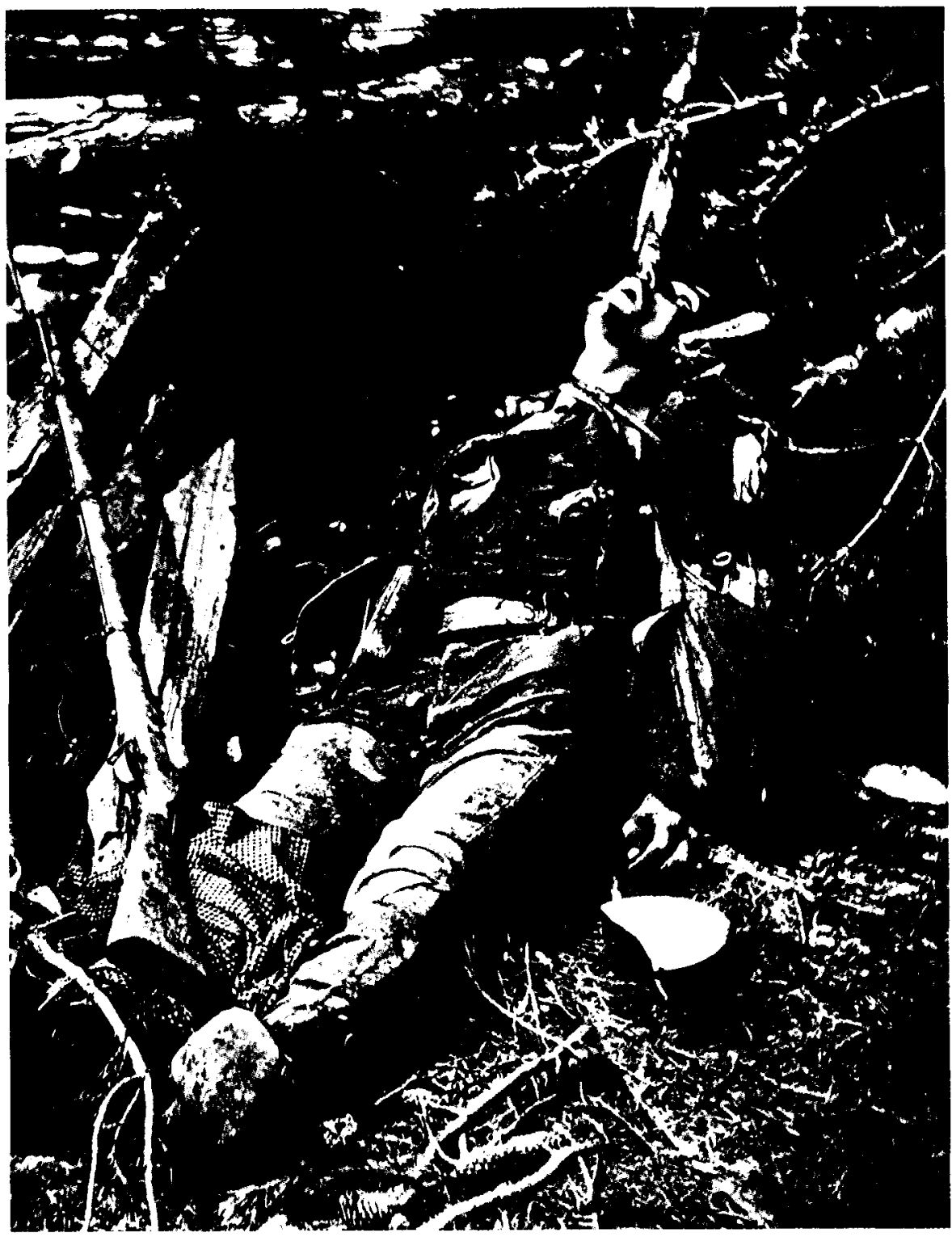

Foto 8. "Confederado muerto en Spottsylvania Court House", 1864. Timothy H. O'Sullivan. 
estético de su época: la elegancia en la guerra, por descontado el valor, invariablemente en posesión del gentlemen victoriano. Pero esta reverencia fue rápidamente superada con una meditada espontaneidad, bien que las composiciones exigiesen un largo y detallado estudio.

Una de estas estudiadas definiciones del ser fentoniano es aquella que muestra a un ayudante sirviendo un vaso de licor a un relajado y apuesto oficial. La escena recoge un rincón aislado del campamento: las blancas tiendas quedan atrás, difuminadas por la escasa profundidad de campo escogida por el fotógrafo; el interés centrado en el simbolismo de esta escena de la vida que triunfa sobre la muerte, de esta cortesía natural ante la ferocidad que puede desatarse en cualquier instante. El respetuoso servidor lleva vestimenta propia de su origen, pero su gesto, con ser solícito, permite una discreta camaradería con el oficial, acción reforzada por el hecho de que éste aparece en mangas de camisa. Hay, pues, una democratización sutil ante la muerte, lejos del hieratismo habitual de clases y estilos castrenses. El breakfast parece haber terminado, platos, tazones y pequeñas marmitas presentan un aspecto evidente de "fuera de servicio". La guerra puede esperar, y de hecho siempre será asi mientras haya un británico en campaña. Sin embargo, la tensión bélica está presente en las guerreras que rodean en círculo y en el sable del oficial, que reposa cuidadosamente a su lado junto a un numeral "28", que identifica al hombre y a su medio como pertenecientes al arma de infantería ${ }^{13}$. Estamos ante un monumento del convencionalismo inglés, pero no por ello menos revolucionario en su plástica: un oficial de rango que admite, sosegado pero inflexible - su serenidad acentuada se intuye puede transformarse en furiosa agresividad-, un sorbo de placer -las diferencias sociales y militares marcadas, pero no despectivas-,

${ }^{13}$ El “28" era el numeral correspondiente al North Gloucestershire Regiment of Foot, que estuvo presente en las batallas de Alma e Inkerman y en el sitio de Sebastopol. El oficial es el teniente coronel Halowell. La obra de Nicholson, J. B. R., The British Army of the Crimea, London, Osprey, 1974, ofrece un espléndido muestrario de la obra de Fenton, junto con cuidadosos detalles de indumentaria y organización del ejército británico, Cfr. LUCIE-SMITH, Edward, The Invented Eye. New York, Paddington Press, 1975, págs. 47 y 48 , 81 y 82: GeRSHEIM, Helmut y Alison, en la edición en español de su original $A$ concise history of photography, London, Thames and Hudson, 1066, presentada en castellano bajo el titulo de Historia Gráfica de la Fotografia, Barcelona, Ediciones Omega, 1967, págs. 139 y 140, hablan asi de las intenciones de Fenton: “... pero esto se explica por el doble propósito de la empresa: vender copias al público (el editor Thomas Agnew propuso a Fenton la idea, después de una sugerencia del Ministerio de la Guerra), al que hubieran horrorizado fotografias cruentas, y dar una prueba convincente del bienestar de las tropas después del desastre del invierno precedente, que habian producido la caida del gobierno (se refiere a Lord Aberdeen). 
todo ellos mientras demuestra poseer el temple suficiente como para disfrutar momentáneamente de la vida, sin que esto disminuya en nada su entereza previsible al afrontar, quien sabe si ese mismo día, una muerte heroica.

Pero si una sola obra identificó un género, determinó un estilo -en su espacio estético - y caracterizó a un autor, ese mérito recae en el original titulado "El valle de la Sombra de la Muerte", una estremecedora visión del horror a posteriori, pero en un plano de densa levitación emocional. Con sensiblidad y agudeza notables, Fenton escogió un desolado escenario en las proximidades de Balaklava, posiblemente parte del terreno recorrido por aquella galopada hacia el absurdo de la Brigada Ligera de lord Cardigan: colinas sin ninguna presencia de vida, vegetal o humana; el cielo desnudo, implacable; las cunetas y los campos que en ellas confluyen saturados de formas esféricas, proyectiles inertes que siguen expresando muerte y devastación, y un camino sin alma, sin sentido, que se pierde en el infinito, en aquella inmensa y opresiva pérdida de la conciencia militar que resultó ser la guerra de Crimea. La sugestión de desamparo, de aniquilación, es completa. No hay ningún cadáver a la vista, ni tan siquiera las presencias "admitidas" del simbolismo bélico establecido: armones volcados, cureñas destrozadas, armas o estandartes mutilados, abandonados; restos heridos y gloriosos y sin embargo asépticos, imposiciones pictoricistas para una representación del honor que imperativamente demandaba una dramatización incruenta que la hiciera así ser admitida como "verdadera".

En la panorámica fentoniana ninguno de estos atributos existen, y sin embargo todos ellos están presentes con su superposición relacionada por el impacto mortal, "real", de estas decenas y decenas de balas de cañón que las llevaron a deshacerse en una nube de furia e impiedad, fortísimo exponencial psiquico de evidente presencia. Sin duda esta reflexión influyó en la pusilanimidad victoriana, que rechazó cortésmente la exposición que se hizo ${ }^{14}$ de estas inquietantes perspectivas, premoniciones matizadas de una verdad todavía sin definir que terminaría por revelarse en toda su trágica dimensión.

14 Fenton llegó a Crimea en marzo de 1855 y volvió en julio a Inglaterra, ya afectado por el cólera. De sus 360 negativos en placas de vidrio al colodión, se positivó una selección que se exhibió en Londres y París con escaso exito. Varios de ellos, mediante el proceso de grabado en madera, sirvieron para ilustrar crónicas del lllustrated London News. Cfr. NEWHALL, Beaumont, Historia de la Fotografia. Desde sus origenes hasta nuestros dias, Barcelona, Gustavo Gili, 1983, págs. 85-87. GERSHEIM, Helmut y Alison, conocido matrimonio de fotohistoriadores, relataron las peripecias de Fenton en su obra Roger Fenton, London, Secker-Wartburg, 1954. 
James Robertson, un detallista británico de los grandes encuadres fotográficos - grabador principal de la Casa de la Moneda en Constantinopla--, tomó el revelo de Fenton y llegó a tiempo de asistir a las últimas masacres en torno a Sebastopol y a la caida misma de la ciudad. Siguiendo medularmente las reservas estéticas -en realidad, políticasde su época, Robertson captaría los efectos devastadores, no por ello menos triunfales, de la artilleria aliada en los fuertes del Gran Redan y de la torre Malakoff, sinónimos de repetidas matanzas. La obra de Robertson siguió a la guerra con modales de refinado cirujano: expuso los escenarios reventados por la metralla, pero antes tuvo la delicadeza de levantar preventivamente muertos y heridos. El resultado fue un silencio lleno de gritos que, pese a ello, se adaptaba sin daño al marco de los viejos grabados, de las grandes pinturas de Salón y Academia, siempre fastuosas y siempre institucionales, defensoras de una elemental teología de la fama y la gloria del Estado a quien servian ${ }^{15}$.

\section{LA GRAN DECISIÓN, COMTE EN TAKÚ Y HEGEL EN GETTYSBURG}

Europa occidental recibió a sus héroes -el Piamonte victor manuelista también habia participado en la gloria - con grandes hogueras y desfiles, como viejos guerreros celtas supervivientes de tormentosas hazañas en los confines de "Inmarama" (viajes legendarios). Se vitoreó la ilusión y con alivio, los muertos quedaban en Crimea; su sacrificio convertido en divinidad, pero su miseria y su asesinato colectivo púdicamente ignorados. Los fotógrafos no participaron de este recibimiento "augusto" y los que volvían con la vida en la mano -otros no lo pudieron

${ }^{15}$ Los originales de Robertson en GERSHEIM, obra citada, pág. 142; y en JOHNSON, Curt, Artillery. The big guns go to war, London, Octopus, 1975, págs. 16 y 17. Cfr. Young, Peter y LAWFORD, J. P., en History of the British Army, London, Arthur Baker Lid., 1972, págs. 159 y 160. Otra buena presentación de los trabajos de Fenton en R. LeVENTHAL, Albert, WAR. The camera's battlefield view of man's most terrible adventure, from the first photographer in the Crimea to Vietman, London, Hamlyn, 1973, págs. 10-21. Adolphe Yvon, seguidor del militarismo glorioso de Meissonier, estuvo en Sebastopol cinco meses después de acabado el drama. Todavía encontró restos humanos en la inextricable confusión de los baluartes destrozados, lo que demuestra el cuidado "exquisito" que puso Robertson en evitarlos. Otro notable pintor de historia militar, Jean-Charles Langlois, marcharía a Crimea acompañado de un fotográfo como ayuda "documentalista" con destino a su lienzo "La prise de Sebastopol", Robichon, F., en "Langlois, soldat, peintre et panoramiste", para Uniformes. Les Armées de l'Histoire, núm. 71, enero 1983, págs. 12-16. En la misma revista, cfr. DelPERIER, L., Yvon, le dernier des classiques, núm. 68, 1982, págs. 12-17. 
lograr ${ }^{16}$-, recibieron un interés meramente compasivo. Robertson, sin embargo, decidió intentarlo de nuevo, y la rebelión de los cipayos (tropas auxiliares) en la India, le sirvió de estímulo viajero. Fiel a sí mismo, Robertson deambuló con sus cámaras por el tumulto hindostánico, pero se limitó a copiar escombros y algún que otro general satisfecho, el efecto "Sebastopol» inseparable de su estética. Pero un audaz veneciado, Félix A. Beato, que le acompañaba como discípulo, entendió muy pronto que el maestro no atendía mínimas imposiciones de la realidad. El cambio se hizo visible en Lucknow, donde la mentalidad de Beato, sin duda por no pertenecer en conciencia a ningún imperio, no tuvo reparos en aceptar la muerte, aunque fuese como ornamento arqueológico más que como testimonio de la furia - los montones de esqueletos de los sublevados contra el poder británico- entre religiones y políticas enfrentadas. Con ser una inflexión importante, el giro interpretativo no estaba globalmente estructurado.

La fotografía y la guerra eran poderes asimétricos; siempre lo han sido, pero hoy sabemos y conocemos que una sola imagen simboliza toda una guerra, explicita toda una crispante teoría de la violencia. Entonces no. En 1859, la Societé Française de Photographie, muy pujante, había obtenido permiso del ministerio de Beaux-Arts, para celebrar una exposición en el palacio de los Campos Elíseos, coincidente con el Salón de la Pintura. No cabía mayor provocación. Y ello dio pie para que Baudelaire arremetiera contra la razón fotográfica: "Es ya hora, pues, de que regrese a su verdadero deber, que es el de servir a las ciencias y a las artes ... pero siendo una muy humilde sirvienta, como lo son la imprenta y la taquigrafía, que ni han creado ni completado a la literatura" ${ }^{17}$. Viniendo de uno de los santones estéticos de Francia, la diatriba debía tomarse muy en serio. Pero la reacción estaba ya gestada dentro del mundo interior de lo sublime, esa pintura que reaccionaba por si misma: "La pintura es un arte esencialmente concreto: sólo puede consistir en la representación de cosas reales y existentes (...) La imaginación artistica estriba en dar con la expresión más completa de una cosa existente, jamás en suponer o crear esa misma cosa (...) Lo bello, como la verdad, es algo relativo: depende del tiempo en que se vive y del individuo capaz

${ }^{16}$ Junto a Fenton y Robertson, otros fotógrafos británicos habian estado en Crimea: Nicklin, Brandon y Dawson. Nickłin murió en el viaje de vuelta, junto con sus dos ayudantes, al naufragar su transporte, el «Rip van Wrinckle», a la altura de Odessa (noviembre 1855). Cfr. Chapuls, Jean-Pierre, Croisade en Crimée 1854-55. La guerre qui arreta les ruses, Paris, SPL, 1977, pág. 156.

17 Newhall, B., obra citada, pág. 83. 


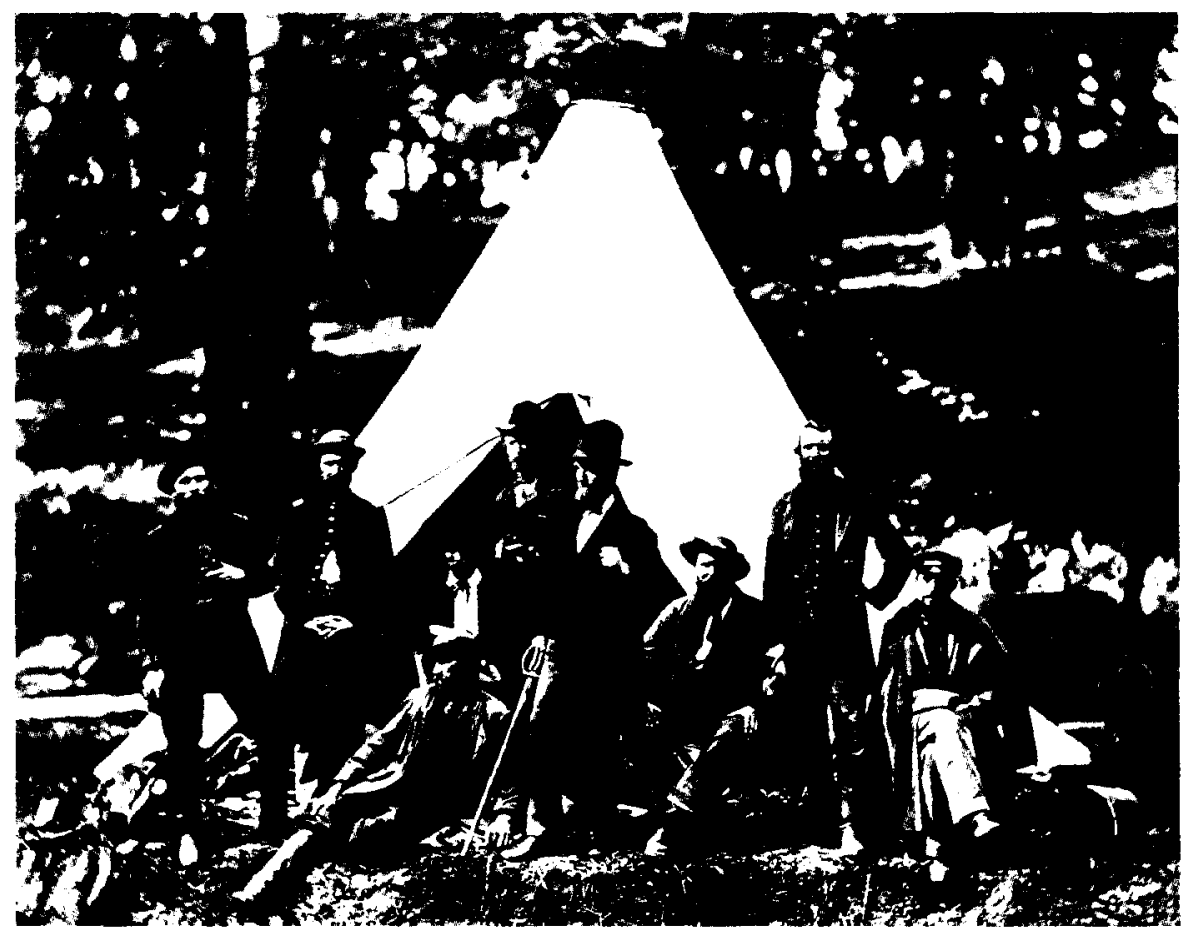

Foto 9. "Exploradores y guias para el Ejército de Potomac", 1862. Alexander Gardner.

de concebirlo" ${ }^{18}$ ¿Quién se expresaba con tanta sinceridad, acaso un nuevo Aristóteles? No, es Gustave Courbet, el autor del «Entierro de Ornans" y de "Los Picapedreros" (ambos de 1850), Una visión "révoltante" de la muerte y el trabajo. A Courbert, como si fuera fotógrafo -él mismo utilizaría el medio para la pose de una modelo desnuda en su cuadro "El estudio del artista», en 1849-, le llovieron los enemigos académicos y populares, pero también los amigos, institucionales unos, como Baudelaire, "méchants» otros, como Proudhon, Daumier, Corot o Jules Hesson, Champfeury, que se expresaba así en "Le réalisme», su manifiesto de 1857: «La reproducción de la naturaleza por el hombre nunca será una reproducción, una imitación, sino que será siempre una interpretación». Aqui estaba la metafísica del problema.

18 VentuRi, Lionello, Historia de la crítica de arte, Barcelona, Gustavo Gili, 1982, pág. 258. 
Mientras esto sucedia, Félix Beato, separado de Robertson, marchó a China, siguiendo los compases intervencionistas de lord Palmerston en su pelea con los emperadores manchués - y más concretamente Hieng Fuong-, por el control de las transacciones del opio y el té. Beato asistió de este modo al encontronazo de ambos poderes en las costas septentrionales del Bo-Hai. El resultado era previsible: toma de Tien-tsin e incendio del Palacio de Verano en Pekin. Pero antes hubo que dominar una línea de resistencia, y el fuerte de Takú era uno de sus puntales. Allí se encontraron la fotografía y el realismo con devastadora sorpresa. Beato llegó a la batalla en el último impulso de los regimientos británicos y no lo dudó en segunda reflexión: aceptaría la verdad, la muerte, pero aguardaría a que la muerte de los vencedores fuese retirada. De esta forma, con su cámara en dos emplazamientos dentro del interior del fuerte conquistado, uno oblicuo y otro siguiendo el eje del asalto británico, compuso una sencuencia que no perdonó ningún escalofrío estético: los cadáveres de los defensores chinos aparecen aplastados contra su legitimidad, que ha sido reventada por los obuses y las bayonetas británicas. Desarticulados, destruidos por completo, pero todavía identificables por sus características coletas, los hombres "extraños" han sido barridos por la técnica, es decir, la razón y el derecho de sus superiores. No hay perdón para ellos, pero la catástrofe interpretada por Beato, con ser parcial, reflexionaba de una simultaneidad de víctimas y preguntas que no por haber sido diferenciadas dejaban de participar de una misma ansiedad. Las escaleras de asalto utilizadas por los infantes británicos testimoniaban de una furia huracanada que por alli había silbado en busca únicamente de la victoria. Beato, con ser respetuoso con ella, aportaba muchos interrogantes, aunque no demasiados. Se había impuesto el positivismo inflexible, acorde con los dictados políticos y la prepotencia de una burguesia occidental expansiva. El Estado mantenia un doble lenguaje: romanticismo hacia el pueblo y realismo estricto en su política.

Las leyes sentenciadas por Comte - «Cours de philosophie positive», 1803-42, y "Système de politique positive, instituant la religion de l'Humanité", 1851-54-, bendecian el orden "natural», esto es, la Sociedad por excelencia y unida al Estado como el cuerpo al deseo. Se implantaba una teología expresa del egoísmo, que en absoluto fue así entendida. Habida cuenta de que el individuo es una abstracción, y la sociedad su sentido real, la espontaneidad (le bons sens) afecta al arte y a la política, pero siempre que esta meditación no derive en anarquía, pues si el hombre tiende a sorprenderse con su entorno (l'étonnement), este asombro no puede llevarle a la indefensión, ya que el hombre, por su propia necesidad de justicia, de seguridad, debe prever, ordenar esas sorpresas y prodigios. 


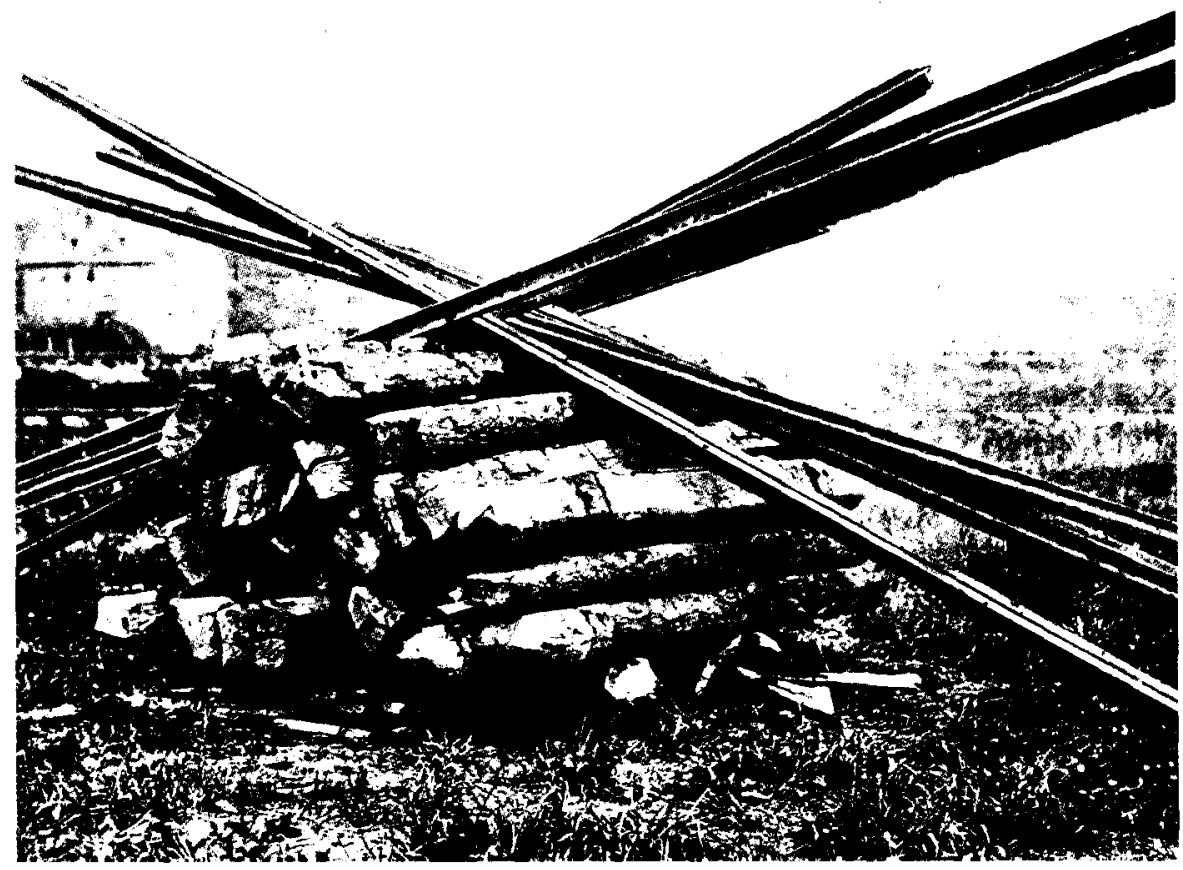

Foto 10. "Las horquillas de Sherman", 1864. George N. Barnard.

Si la filosofía de Comte influyó en Beato de forma instintiva (por la exigencia de una política), pero dotándole de un pragmatismo "atrevido", más trascendencia tendria en Hyppolite Taine, cuya metodología del arte influyó en no pocas conciencias. Taine se expresaba asi: "Para entender una obra, a un artista o a un grupo de artistas, es preciso hacerse una clara idea del estado general del espíritu y de las costumbres del tiempo al que pertenecen". Lionello Venturi, que analizó el espiritu de la estética en Taine ${ }^{19}$, señala esta conclusión: "Donde empieza el error es cuando Taine cree que dicho milieu es la "causa" de la pintura". Claro está, Taine, Comte y Beato entendieron el arte, la sociedad, la vida, en función de un determinismo histórico que, inevitablemente, venía condicionado por el hecho político y se tradujo en una manipulación de su ética, artística y social.

Un mundo de tan densa y compleja acumulación histórica como el europeo había llegado al límite de su expresividad estética. Curiosa-

19 Ibidem, págs. 218 y 219. 
mente, estas limitaciones, que estaban siendo vertiginosamente traspasadas por las grandes artes, no lo eran por esa advenediza titubeante conocida como «fotografía». Tendría que ser otro mundo, otras convulsiones; otros entablamentos sociopolíticos los que permitieran el cerramiento de un nuevo orden concebido en función de un respeto a la verdad, verdad absoluta, verdad hegeliana y paradójicamente, ya que surgía en un espacio que siempre le volvería la espalda en su concepción de la sociedad y la política. La guerra de Secesión serviria de gigantesco detonante de estas angustias del ser norteamericano.

El cambio se impuso desde el principio. ¿Era romántica la guerra entre el Sur y el Norte? La majestuosidad -a veces también la insufrible necedad- de una flora literaria y gráfica desbordante dan prueba de ese romanticismo. Libertadores y esclavistas. Granjeros e industriales. La tradición y la revelación. Hombres del campo frente a hombres de la ciudad. La fábrica contra la naturaleza. Mundo viejo y mundos nuevos. Nunca fueron tan extensos y poderosos los factores en una batalla romántica, combate en el que el realismo y el idealismo también participaron con sin igual crudeza.

Pero el espíritu norteamericano era un sentimiento que conectaba automáticamente con la razón, con la verdad. Estuvo en Jefferson y en Franklin, y lo seguía estando con Lincoln. Por respeto a ese mandato, los delegados de las trece colonias habian jurado la primera Constitución defensora de los Derechos del Hombre en 1787. En el mundo de la prensa, incluso del Congreso de la Unión, desde luego en el amplísimo capítulo de los sucesos de Daguerre y Talbot - los EE.UU., ofrecian entonces la mayor densidad de fotógrafos del mundo-, esa verdad era una conciencia implícita a la que no estaban dispuestos a renunciar. De esta forma, un profesional sumamente prestigiado como Matthew Brady se decidió por la aventura, y con él las instituciones unionistas, militares y parlamentarias, aunque nadie intuía la potencialidad revolucionaria de este afán que se entendió sólo como necesidad documentalista y voluntad "romántica».

Brady, que en los primeros compases de la contienda (Bull-Run) actuó solo, comprendió pronto que las dimensiones de la tragedia y su posibilismo gráfico exigian nuevos brazos, nuevas miradas que completasen la definición del gigantesco choque. De esta multiplicidad $-y$ de la capacidad de gestión de Brady- surgió una vibrante estética. El "Brady's Corps" reunió en sus filas a lo más atrevido - y bien preparado técnicamente-, de la fotografía norteamericana. Muchos otros siguieron sus pasos - sólo en el Ejército del Potomac se cursaron pases para 
primera línea a trescientos fotógrafos ${ }^{20}$-, pero ellos fueron los que marcaron el estilo, determinaron una escuela que, desafortunadamente, con ellos nació y en ellos desapareció: Timothy $\mathrm{H}$. O'Sullivan, Alexander Gardner y George N. Barnard, por citar sólo su mejor trilogía expresiva.

Desde las Ilanuras de Tennesee a las colinas de Georgia, estos hombre sufrieron con el clima y los vivacs agotadores; arrastraron pesados equipos que no perdonaban el más mínimo fallo; arrostraron el fuego y el miedo; vacilaron ante la gravedad del horror por ellos descubierto y finalmente lo aceptaron como propio, no como ideal, sino como evidencia de la historia. Víctimas y testigos fueron asi uniformados por la misma vergüenza, por idéntica crueldad, pues unos sufrieron por la aniquilación de otros, y muchos comprendieron la afrenta común a la civilización por el simple hecho de ser copartícipes (en la defensa temporal de unos ideales), espectadores que asistían horrorizados a la materialización de esos conceptos.

En Gettysburg, donde el vértice de la lucha entre ambos contendientes osciló durante tres días de furioso vértigo (1-3 de julio de 1863), O'Sullivan recorrió a pie aquel escenario de pesadilla poco después de que el humo y los gritos se apaciguasen lentamente. Con la cámara situada en un plano bajo, O'Sullivan enmarcó una estremecedora perspectiva: cuerpos deformes, a punto de estallar por su prolongada exposición a la impiedad, la colina entera cubierta de masas irreconocibles, nombres rotos, perdidos ya, espíritus anónimos fusilados a mansalva. La delicadeza de Robertson, la psicología de Fenton y el positivismo de Beato quedaban pulverizados por este escalofriante relato de lo absoluto. Aquellos hombres habían sido victimas de una aterradora caceria por otros hombres. Confederados y nordistas, todos entremezclados en la más depravada ideologización homicida. Fue el más rotundo manifiesto antiheroico, la más profunda herida al romanticismo político, la afrenta no menos mortal a las mentiras. ¿Qué había sido de las banderas, de los sables erguidos hacia el cielo, de las bayonetas apuntando al corazón del odiado enemigo? Todos habían muerto, no había vencedores. El arte y la política se encogieron sobre sí mismos, asustados, confusos. La gloria había muerto, en realidad violada, aquella mañana de julio de 1863.

${ }^{20}$ NeWHaLl, B., obra citada, pág. 89. Newhall recuerda el análisis del New York Times en su edición del 20 de noviembre de 1862, sobre los originales de Brady, "los muertos en Antietam" (una de las primeras grandes batallas de la guerra, 17 de septiembre, 25.000 bajas entre ambos bandos): «Brady ha realizado algo para hacernos presentes la terrible realidad y seriedad de la guerra. Si no ha traido cuerpos y los ha tirado frente a nuestras puertas y a lo largo de las calles, ha hecho algo muy parecido" (pág. 91). 
En su medular concepción del ser, Enciclopedia de las ciencias filosóficas (1817-1830), Hegel buscaba la identificación absoluto-verdad, que ya estaba presente en su Fenomenología del Espíritu (1807): "Lo verdadero es el todo", globalidad que no encajaba en la compartimentación de las conciencias instituida por los regímenes falsamente románticos. Hegel insistió en su tensión de hombre, cosmos y verdad: "Todo lo racional es real y todo lo real es racional's. ¿La hecatombe de Gettysburg era racional en su atentado contra la razón? Era simplemente real, una continuidad del hombre que no por menos irracional dejaba de ser verdad. O'Sullivan no volvió la espalda a esa certidumbre; la fotografía, en su irrefutabilidad, convirtiendo la realidad en imperativa lógica del horror, en consciente aceptación de nuestra verdad histórica.

El hombre, su recorrido social y político, y su devenir trágico, "natural» también, se encontraton en Gettysburg. ¿Acaso este encuentro presuponía un pesimismo ontológico, insuperable? Aquellos cuerpos destrozados eran no sólo el óbito de la gloria, paracian sintetizar el desamparo del hombre moderno, la muerte de Dios. Hegel buscó la luz, una luz especialmente densa en la filosofía de los contrarios y que le iluminó desde el Evangelio de San Juan, la resurreción y la vida en ofrecimiento al que posea la fe. Hegel trasciende esa tensión dúctil y afirma que la muerte pertenece a la esencia de Dios, pues es connatural a él, morir para renacer a una nueva vida. Los crucificados de 1848 o 1855, desviados de la verdad en París o Sebastopol por Bayard y Robertson, incluso la parcialidad letal de Beato en una escuela de infinitos discípulos hasta nuestros días, morian por dos veces: la estética oficialista los arrojó al pudridero de lo oculto, lo prohibido, imponiendo la victoria sobre la compasión, derrotados y vencedores triturados por este egoísmo comtiano. Sin embargo, se les facilitó una representación pictoricista, falsa, "heroica», en los altares académicos de la fama institucional. Una segunda muerte.

La verdad de O'Sullivan y Gradner, incluso la abstracción demoledora de Barnard - su simbolismo concluyente de maderos y raíles dispuestos para la pira final del Sur romántico-, son verdades resurrectas, certezas que persiguen el aprendizaje de la razón, por dura que ésta sea, pues las mentiras nunca podrán garantizar verdad alguna. Los hombres destruidos en aquella guerra, en todas las guerras por la vesanía de dogmas, familias de Estado o intereses estratégicos, murieron para vivir en nuestras conciencias, ese morir para renacer que Hegel hizo suyo, ese "circulo de círculos" que consigue que los muertos de Gettysburg no hayan sido olvidados. No importan los millones que sufrieron después idéntico destino; importa que allí, por primera vez, se les respetó como hombres y se acusó a sus asesinos: nosotros mismos, la razón perdida. 